\section{Cognitive restructuring for compulsive buying}

\author{
Reestruturação coginitiva para compras \\ compulsivas
}

Dear Editor,

Compulsive buying (CB), or Oniomania (from the Greek: oné - shopping, mania - frenzy), is characterized by excessive preoccupations and desire to purchase objects, and unrestrained shopping to the point of personal suffering and financial hardship ${ }^{1}$. The criteria proposed by McElroy ${ }^{2}$ are the most used until nowadays, since both DSM and ICD have not proposed operational criteria for this syndrome, which is classified as an impulse control disorder not otherwise specified. If CB was officially recognized, it would become the most common impulse control disorder, with prevalence estimates ranging from 2 to $8 \%$ of the adult population ${ }^{1}$.

Cognitive behavioral therapy (CBT) has shown promising results for $\mathrm{CB}$ with significant decrease of shopping time and episodes compared to a waiting-list ${ }^{3}$. However, this and other CBT programs for CB do not encompass, or at least have no described cognitive restructuring techniques aiming at cognitive distortions specific to shopping behavior. Keeping this in mind, we developed a CBT program for $\mathrm{CB}$ aiming at identifying and changing cognitive patterns that influence shopping behavior, raising awareness of high risk situations. Table 1 summarizes the content of the 20 weekly group sessions. Sessions 6,7 and 8 are dedicated to cognitions most commonly related to shopping among compulsive buyers: shopping as a way of coping with emotions, shopping as a way of building an identity, and "all or nothing" type of thinking applied to shopping ${ }^{1}$.

The purpose of this communication is to report the outcome of our pilot CBT group with an emphasis on cognitive restructuring for $\mathrm{CB}$. The group consisted of nine individuals, only one male, mean age of 41.8 years-old, only three married, all meeting McElroy's criteria for CB. Psychiatric comorbidity was assessed by the Mini International Neuropsychiatric Interview $(\mathrm{MINI})^{4}$. Seven out of

Table 1 - Group СBT and cognitive restructuring for compulsive buying

\begin{tabular}{|c|c|}
\hline Sessions & Content \\
\hline Week 1 & Introducing the cognitive-behavioral model \\
\hline Week 2 & Pros and cons of compulsive versus sober shopping \\
\hline Week 3 & Stages of change model \\
\hline Weeks 4 and 5 & Why shopping has become a problem \\
\hline Weeks 6,7 and 8 & Most common misconceptions about shopping \\
\hline Week 9 & $\begin{array}{l}\text { Learning to differentiate compulsive from regular } \\
\text { shopping }\end{array}$ \\
\hline Week 10 & Shopping: pleasant o unpleasant? \\
\hline Week 11 & $\begin{array}{l}\text { Understanding domestic economy and financial } \\
\text { planning }\end{array}$ \\
\hline Weeks 12 and 13 & Shopping and debts: negotiating with creditors \\
\hline Weeks 14 and 15 & Relapse prevention: planning the future \\
\hline Weeks 16 and 17 & $\begin{array}{l}\text { Shopping and negative emotions: dealing with } \\
\text { negative thoughts }\end{array}$ \\
\hline Week 18 & Shopping and problem solving \\
\hline Week 19 & Shopping and the circle of life \\
\hline Week 20 & Future directions and closure \\
\hline
\end{tabular}

YBOCS-SV

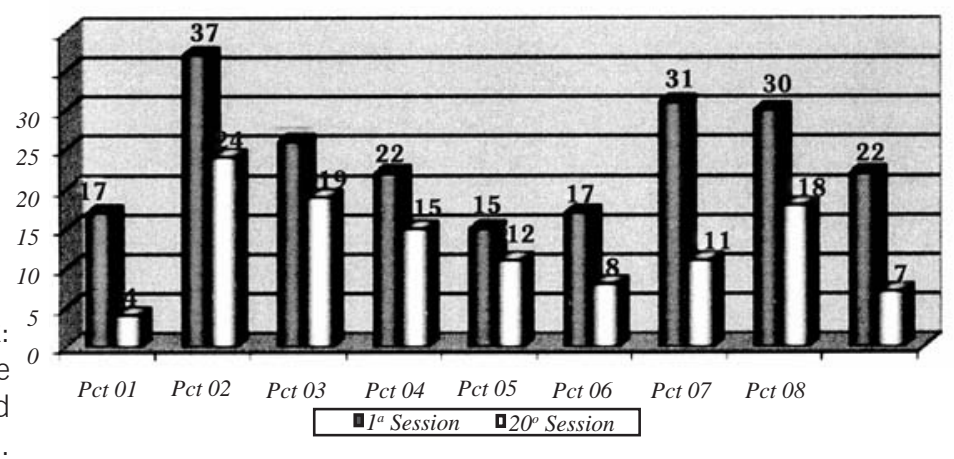

Figure 1 - YBOCS-SV pre and post-treatment

the nine participants presented a current depression, and two of them met criteria for bipolar disorder, but their loss of control over shopping was not better explained by their mood disorders, since shopping bouts also occurred during periods of euthymia.

Participants answered the Yale-Brown Obsessive-Compulsive Scale-Shopping Version (YBOCS-SV) ${ }^{5}$, at the beginning and at the end of treatment. The YBOCS-SV is a 10-item scale; the first five questions are added up to produce a cognitive score (COG), and the last five ones produce a behavioral score (BEH). COG and $\mathrm{BEH}$ scores can be added to produce one last total score (TOT). TOT varies from 0 to 40 , indicating the severity of the shopping psychopathology.

We used Wilcoxon Signed Ranks tests to compare pre and post-treatment scores. COG (pre-treatment median/post-treatment median $=12 / 6, Z=-2.68, p=0.007)$, BEH $(10 / 6, Z=-2.67$, $\mathrm{p}=0.008)$ and TOT $(22 / 11, \mathrm{Z}=-2.67, \mathrm{p}=0.008)$ significantly decreased after CBT treatment - see Figure 1.

The conclusion is that group therapy with an emphasis on detection of specific shopping cognitive distortion and restructuring may help compulsive buyers in dealing with both cognition and shopping behavior. Controlled studies are warranted in order to determine the generalizability of the present findings and to compare different approaches to this troublesome, and yet poorly recognized disorder.

Tatiana Zambrano Filomensky, Hermano Tavares Impulse Control Disorders Outpatient Unit, Institute and Department of Psychiatry, Universidade de São Paulo (USP), São Paulo (SP), Brazil 


\section{Disclosures}

\begin{tabular}{|c|c|c|c|c|c|c|c|}
\hline $\begin{array}{l}\text { Writting group } \\
\text { member }\end{array}$ & Employment & $\begin{array}{l}\text { Research } \\
\text { grant }^{1}\end{array}$ & $\begin{array}{c}\text { Other research grant or } \\
\text { medical continuous } \\
\text { education }\end{array}$ & $\begin{array}{l}\text { Speaker's } \\
\text { honoraria }\end{array}$ & $\begin{array}{l}\text { Ownership } \\
\text { interest }\end{array}$ & $\begin{array}{l}\text { Consultant/ } \\
\text { Advisory } \\
\text { board }\end{array}$ & Other $^{3}$ \\
\hline $\begin{array}{l}\text { Tatiana Zambrano } \\
\text { Filomensky }\end{array}$ & USP & --- & --- & -- & --- & --- & --- \\
\hline Hermano Tavares & $\begin{array}{c}\text { USP }^{*} \\
\text { ANJOTI* }^{*}\end{array}$ & FAPESP ${ }^{* *}$ & --- & $\begin{array}{l}\text { Janssen-Cilag* }^{*} \\
\text { Instituto Américo } \\
\text { Bairral }\end{array}$ & --- & --- & $\begin{array}{c}\text { Lundbeck }^{*} \\
\text { Servier* }^{*} \\
\text { Roche* }^{*} \\
\text { Apsen }^{*} \\
\text { Wyeth }^{*} \\
\text { Sandoz* }^{*} \\
\text { Abbott } \\
\text { Cristália } \\
\text { Editora Artes Médicas } \\
\text { TAM Linhas Aéreas }\end{array}$ \\
\hline
\end{tabular}

\section{* Modest}

** Significant

*** Significant. Amounts given to the author's institution or to a colleague for research in which the author has participation, not directly to the author.

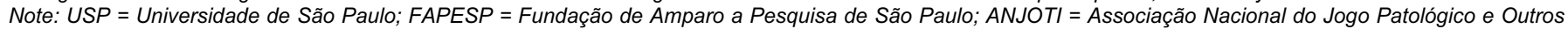
Transtornos do Impulso.

For more information, see Instructions for authors.

\section{References}

1. Tavares H, Lobo DS, Fuentes D, Black DW. Compulsive buying disorder: a review and a case vignette. Rev Bras Psiquiatr. 2008;30(Suppl 1):S16-23.

2. McElroy SL, Keck PE Jr., Pope HG Jr., Smith JM, Strakowsiki SM. Compulsive buying: a report of 20 cases. J Clin Psychiatry. 1994;55(6):242-8.

3. Mitchell JE, Burgard M, Faber R, Corsby RD, de Zwaan M. Cognitive behavioral therapy for compulsive buying disorder. Behav Res Ther. 2006;44(12):1859-65.

4. Amorim P. Mini International Neuropsychiatric Interview (MINI): validation of a short structured diagnostic psychiatric interview. Rev Bras Psiquiatr. 2000;22(3):106-15.

5. Monahan P, Black DW, Gabel J. Reliability and validity of a scale to measure change in persons with compulsive buying. Psychiatry Res. 1996;64(1):59-67. 